\title{
An Acoustical Approach to the Study of the Wagons of the York Mystery Plays: Structure and Orientation
}

The staging of the York Mystery Plays has been the subject of numerous research articles. Only limited attention has been paid, however, to the acoustics of the performance spaces. This paper discusses how digital technology can be applied to the exploration of the acoustical effects different types of wagon structures and orientations might have had on the spoken and sung items of the plays by focusing on their interaction with one of the sixteenth-century playing stations: Stonegate.

The scarcity of information in relation to the staging and performance of the York Mystery Plays in medieval times has made it necessary for scholars to draw information and methodologies from different fields of study. Existing theories on the staging, performance, and reception of the plays have used as sources the surviving documents, ${ }^{1}$ the findings regarding the streets used for the performances, ${ }^{2}$ research into similar events in continental Europe, ${ }^{3}$ as well as experience gained in modern productions. ${ }^{4}$

Although scholars have acknowledged that acoustic considerations might have been an important factor in performance and staging decisions, ${ }^{5}$ we lack systematic studies on how acoustic considerations would have had an impact on the staging and reception of the plays. The advent of new digital technologies allows the application of acoustical knowledge to the study of the York Mystery Plays through the use of computer models.

In this paper, I build upon my previous work on the acoustics of one of the playing stations of the York Mystery Plays: Stonegate, a street in central York. I studied Stonegate through acoustic measurement techniques and virtual models in order to explore both its modern and sixteenth-century acoustics. ${ }^{6}$ This article explores three different but interconnected issues: the impact of the introduction of wagon structures on the acoustics of sixteenth-century Stonegate; the changes in the acoustics of the space depending on the type

Mariana Lopez (mariana.lopez@anglia.ac.uk) is a postdoctoral researcher in the Cultures of the Digital Economy Research Institute, Anglia Ruskin University. 
of wagon structure used; and the impact of wagon orientation on the acoustics of the performance space. I focus on the impact of the wagons on the performance space, rather than on the effects of audience areas (standing, seated, at windows), as I have analysed the latter in a previous study. ${ }^{7}$

\section{Computer Models: Stonegate, Wagon Types, and Wagon Orientation}

In a previous study I explored the use of computer models designed using the software CATT-Acoustic to study the characteristics of sixteenth-century Stonegate. ${ }^{8}$ I simulated eight different models to explore the impact of differences in the height of buildings, open versus closed windows, and window types (in line with the wall versus projecting). Using multiple computer models avoids a reductionist approach to the study of sixteenth-century Stonegate by bringing to the forefront areas of uncertainty in connection to its features. I did not consider audience areas as part of these acoustic simulations given my aim of first exploring the different unknowns in connection to the acoustics of Stonegate while also establishing the structural variations that are most important for acoustical studies on the performances. Results demonstrated that changes in buildings' height as well as variations between open and closed windows would have had a significant impact on the acoustics of Stonegate, whereas changes in window types would have had a minimal effect and, as a result, represent an aspect that can be disregarded in future studies.

For this article, I used four different virtual models of sixteenth-century Stonegate (those whose characteristics were relevant in terms of acoustics see table 1) and combined them alternately with the simulations of two different wagon structures, with two different orientations. I explore the impact of these different wagon structures and orientations in terms of the effects they might have had on the acoustics of Stonegate and, as a result, on the performance and reception of the York Mystery Plays. 
Table 1. Computer models of sixteenth-century Stonegate

\begin{tabular}{cccc}
\hline $\begin{array}{c}\text { version of sixteenth- } \\
\text { century Stonegate }\end{array}$ & $\begin{array}{c}\mathrm{n}^{\text {o }} \text { of storeys for } \\
\text { the majority of the } \\
\text { buildings }\end{array}$ & $\begin{array}{c}\text { glass on upper stor- } \\
\text { eys/wooden shutters } \\
\text { on ground floor }\end{array}$ & $\begin{array}{c}\text { windows in line with } \\
\text { the wall }\end{array}$ \\
\hline 1 & 2 & yes & yes \\
2 & 2 & no & yes \\
3 & 3 & yes & yes \\
4 & 3 & no & yes \\
\hline
\end{tabular}

My acoustical analysis focuses on three main points. First, the impact of the addition of a wagon structure on the acoustics of the street space becomes evident through a comparison of the results from the acoustic predictions of the space including a wagon to the results derived from the same space without a wagon included. Second, my study explores variations in the acoustical properties of the space dependent on the introduction of a closed or open wagon structure. Third, I measure acoustical changes resulting from different wagon orientations (side-on versus front-on).

\section{Wagon Structures}

My study simulated two contrasting wagon structures and measured the resulting effects on the acoustics of sixteenth-century Stonegate with respect to a side-on and front-on orientation for each wagon (see figure 1 and table 2). ${ }^{9}$

The first type of wagon (referred to in this article as 'closed' wagon) is a multi-level design with its lower section, which represents Earth, closed on three sides (see figures 2 and 3). I modelled the base of the wagon structure through the simulation of curtains covering the wheels. The main deck has a wooden surface, and the sides are wooden frames with curtains. The upper deck, which represents Heaven, has a wooden base and a wooden surface at the back, but it is open on the left- and right-hand sides. The complexity of the structure, the inclusion of two different levels, and the use of cloth for the back and sides of the wagon are based on the 1433 Mercers' wagon of 'The Last Judgement'. ${ }^{10}$ John McKinnell's work ${ }^{11}$ provided the basis for determining the dimensions of the wagon structure. In its side-on orientation, the 
i4 Mariana Lopez

\section{STREET FACADE}

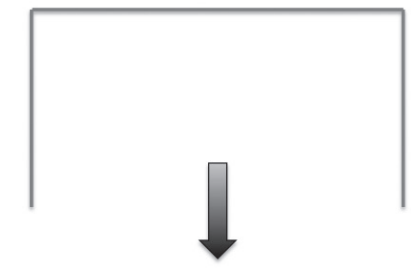

\section{STREET FACADE}

\section{STREET FACADE}

\section{STREET FACADE}

Figure 1. Wagon orientation, (a) side-on orientation, (b) front-on orientation 
wagon has a depth of $1.83 \mathrm{~m}$ and a length of $3.66 \mathrm{~m}$, values that are inverted in the front-on orientation. The height of the wagon from the street level to the topmost part of the structure is $6.7 \mathrm{~m}$. Such height includes the following elements and their respective heights: a deck $(1.83 \mathrm{~m})$, the Earth structure $(2.44 \mathrm{~m})$, the wooden base of Heaven $(0.25 \mathrm{~m})$, and the Heaven structure $(2.18 \mathrm{~m})$. The height of the wagon deck is based on McKinnnell's ${ }^{12}$ analysis of documents on the Chester Cycle, the Flemish ommegangen in van Alsloot's painting The Triumph of Archduchess Isabella (1615), ${ }^{13}$ and the wagons used in Spanish Easter week processions. The height of the Earth structure is based on the height chosen in 'The Last Judgement' productions by Joculatores Lancastrienses (1988) and the Durham Medieval Theatre Company (1998). ${ }^{14}$ The height of Heaven needed to be comparable to the Earth structure as well as to bring the wagon structure up to the height of $6.7 \mathrm{~m}$, which is the minimum height McKinnell considers possible for a multi-level wagon. ${ }^{15}$ The choice of wagon depth takes into account the narrow width of the streets of medieval York as well as the need for a 'backstage' area for side-on wagons. ${ }^{16}$ These dimensions could be increased in future experiments in order to analyse the impact of the change on the acoustics of the space.

Table 2. Characteristics of the simulated wagons

\begin{tabular}{l}
\hline Wagons Simulated \\
wagon closed on three sides with a side-on orientation \\
wagon closed on three sides with a front-on orientation \\
wagon open on four sides with a side-on orientation \\
wagon open on four sides with a front-on orientation \\
\hline
\end{tabular}

The second type of wagon (referred to in this article as 'open' wagon) is based on the Nativity wagon in van Alsloot's painting. The computer model consists of a wooden wagon deck that is covered with curtains, and a wooden pitched roof supported by four wooden columns (see figure 4). The dimensions are the same as the closed wagon with the exception of the height from street level to the top of the roof, which is $6.17 \mathrm{~m}$.

In acoustical models, assigning surface materials requires the use of absorption and scattering coefficients. Sound absorption is the removal of acoustic energy from a space, whereas scattering refers to non-specular sound 


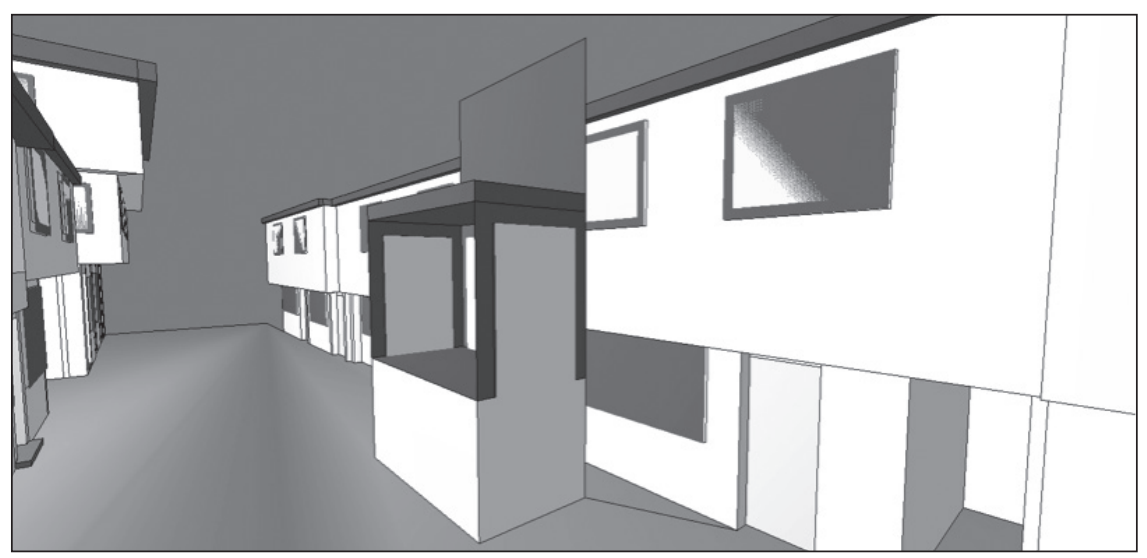

Figure 2. Wagon structure closed on three sides with a side-on orientation and incorporated to version one of the sixteenth-century simulations

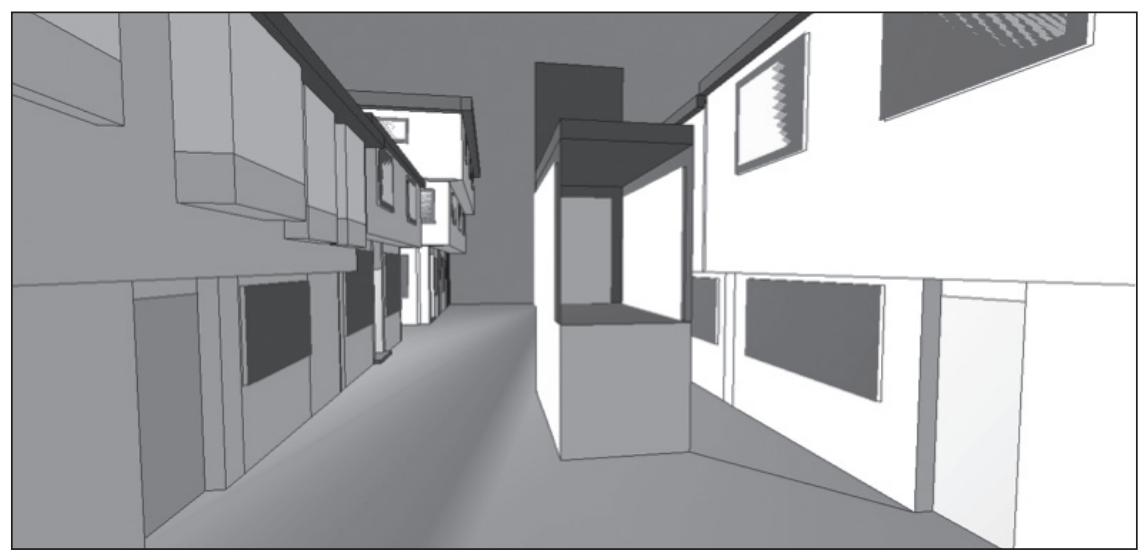

Figure 3. Wagon structure closed on three sides in a front-on configuration and incorporated to version one of the sixteenth-century simulations

reflections caused by the irregularities of surfaces. The choice of materials for the virtual models, which are in most cases wooden surfaces, reflects the importance of timber in the construction of medieval vehicles. ${ }^{17}$ I sourced the absorption and scattering values (see table 3 ) from the Surface Properties Library in CATT-A, ${ }^{18}$ which includes surfaces used for the study of auditorium acoustics. These values, however, could be modified to reflect different possible types of timber as well as different types of curtains. In future publications I will explore these alternatives. My study disregarded details 


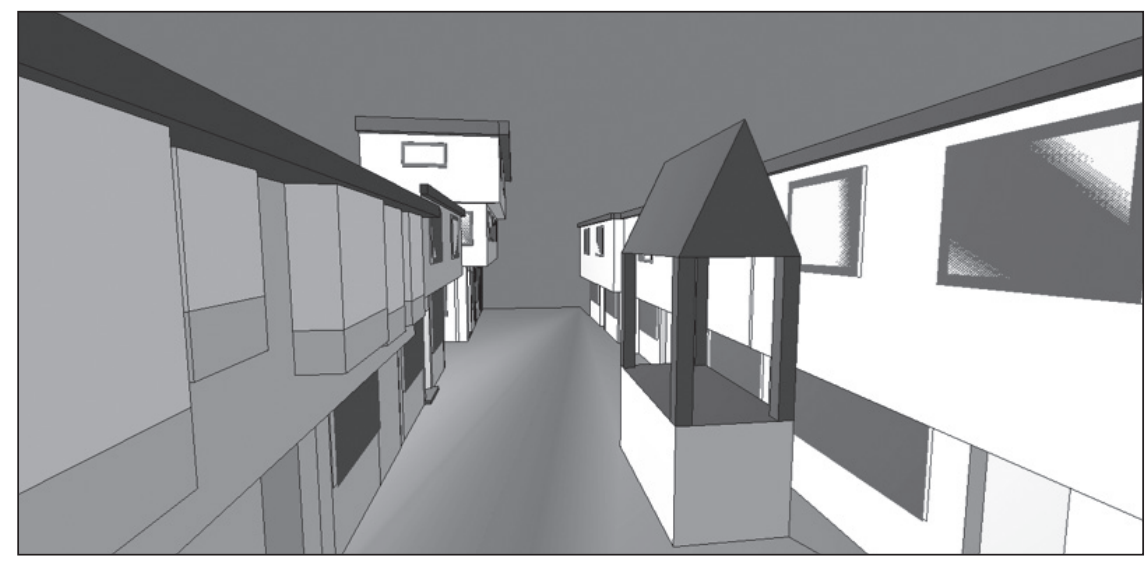

Figure 4. Wagon structure open on all sides and incorporated to version one of the street model

pertaining to the undercarriage and the tongues, as they are not essential to the study of the acoustics of the space. Other features the models excluded are those relating to practical aspects such as machinery employed for theatrical effects; in the case of the multi-level wagon this machinery would have been used to simulate the ascent of God to Heaven. My study also omitted practicalities concerning the ascent and descent of actors and singers to the acting decks, which might have involved the use of ladders. ${ }^{19}$

Table 3. Absorption and scattering values used for the wagon structures, expressed in percentages (values sourced from the Surface Properties Library in CATT-A) ${ }^{20}$

\begin{tabular}{|c|c|c|c|c|c|c|c|c|}
\hline \multirow{2}{*}{$\begin{array}{c}\text { surface } \\
\text { materials }\end{array}$} & \multicolumn{8}{|c|}{ frequency } \\
\hline & $125 \mathrm{~Hz}$ & $250 \mathrm{~Hz}$ & $500 \mathrm{~Hz}$ & $1 \mathrm{kHz}$ & $2 \mathrm{kHz}$ & $4 \mathrm{kHz}$ & $8 \mathrm{kHz}$ & $16 \mathrm{kHz}$ \\
\hline \multicolumn{9}{|l|}{ curtains } \\
\hline absorption & $5 \%$ & $12 \%$ & $15 \%$ & $27 \%$ & $37 \%$ & $50 \%$ & $63 \%$ & $76 \%$ \\
\hline scattering & $10 \%$ & $10 \%$ & $10 \%$ & $10 \%$ & $10 \%$ & $10 \%$ & $10 \%$ & $10 \%$ \\
\hline \multicolumn{9}{|l|}{$\begin{array}{l}\text { wooden } \\
\text { surfaces }\end{array}$} \\
\hline absorption & $11 \%$ & $7 \%$ & $3 \%$ & $1 \%$ & $1 \%$ & $2 \%$ & $3 \%$ & $4 \%$ \\
\hline scattering & $10 \%$ & $10 \%$ & $10 \%$ & $10 \%$ & $10 \%$ & $10 \%$ & $10 \%$ & $10 \%$ \\
\hline
\end{tabular}




\section{Sound Sources and Receivers}

I added virtual sound sources to the computer models to simulate performers (actors/singers) and receivers to represent listeners (audience members). The wagon closed on three sides includes five different sound sources (see figure 5), which represent performers standing at various positions in relation to the wagon structure. Two sound sources were located atop the wagon deck, one of them towards the back of the structure (B0) and the other towards the front (B1). Another source was located at street level in front of the wagon (B2) and two more sources were located atop the upper deck, one of them towards the back of the structure (B3) and the other towards the front (B4). The virtual models that include the wagon open on all sides only include sources B0 to B2. All sound sources are oriented towards the listeners.

Three different listener positions are included (see figures 6-7); previous work on Stonegate uses these same positions, ${ }^{21}$ which follow the recommendations by Gade ${ }^{22}$ for acoustical studies.

\section{Virtual Models}

The study combined each wagon simulation (see table 2) in turn with the four virtual models of sixteenth-century Stonegate (see table 1), resulting in sixteen simulations of the acoustics of the performance space.

The study of the acoustical characteristics of the performance spaces through such simulations needs to consider both speech and music. The plays relied upon intelligible speech to transmit the essential religious message to the audiences; in many instances in the plays, words are more important than the actions assigned to the characters. ${ }^{23}$ The ability of actors to project their voices in outdoor spaces, furthermore, was considered vital for their participation in the York Mystery Plays, highlighting the relevance of speech clarity. ${ }^{24}$

Several of the plays also included music, especially in connection to angels and good secular characters. ${ }^{25}$ We identify the use of musical items in the York Mystery Plays not, in most cases, through the inclusion of notated music in the manuscript but by analysing dramatic directions, text references, Latin phrases, and the extant records on the plays. ${ }^{26}$ Scholars have interpreted the lack of notated music as an indication that the performers sang the pieces monophonically (that is, in a plainchant setting, which was the predominant musical style of worship), to improvised polyphony (two or more melodic 


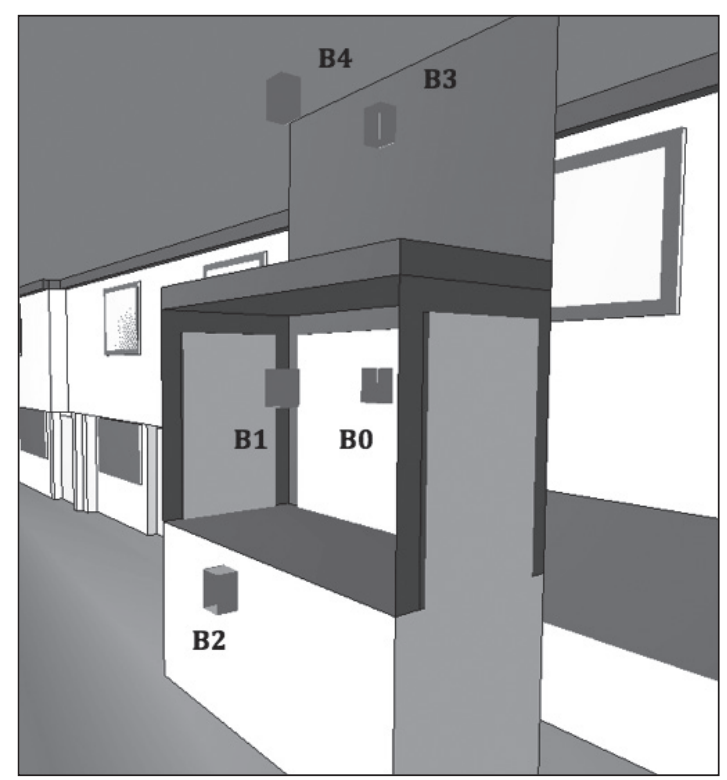

Figure 5. Sound source positions for the closed wagon with a side-on orientation

lines), or that these singers knew a polyphonic version of the piece. ${ }^{27}$ The only surviving notated music, from 'The Assumption of the Virgin', consists of three texts with two polyphonic versions of each.

Because of the importance of speech and music in the plays, I will analyse the acoustics of the performance spaces in terms of reverberation time, clarity, and Apparent Source Width (ASW).

Reverberation time, often referred to as RT60, can be defined as the time, expressed in seconds, that it takes for sound to decay by $60 \mathrm{~dB}$ after the sound source has stopped emitting sound. Although the definition of reverberation time considers a $60 \mathrm{~dB}$ dynamic range, scholars often measure values over a narrower range of $30 \mathrm{~dB}$; this article considers such values, referring to them as T30. The optimum reverberation time for a space depends on its function. If a space is used mainly for the spoken word, then short reverberation times are preferable. Literature suggests one second as the ideal reverberation time for speech, although acoustic measurements in theatres have shown that values can range between 0.7 and 1.2 seconds. ${ }^{28}$ Below 0.5 seconds, although speech will be intelligible, listeners might feel aural discomfort as most people usually inhabit and frequent spaces with reverberation times above 0.5 of a second, making spaces with very low reverberation times seem unnatural. ${ }^{29}$ 


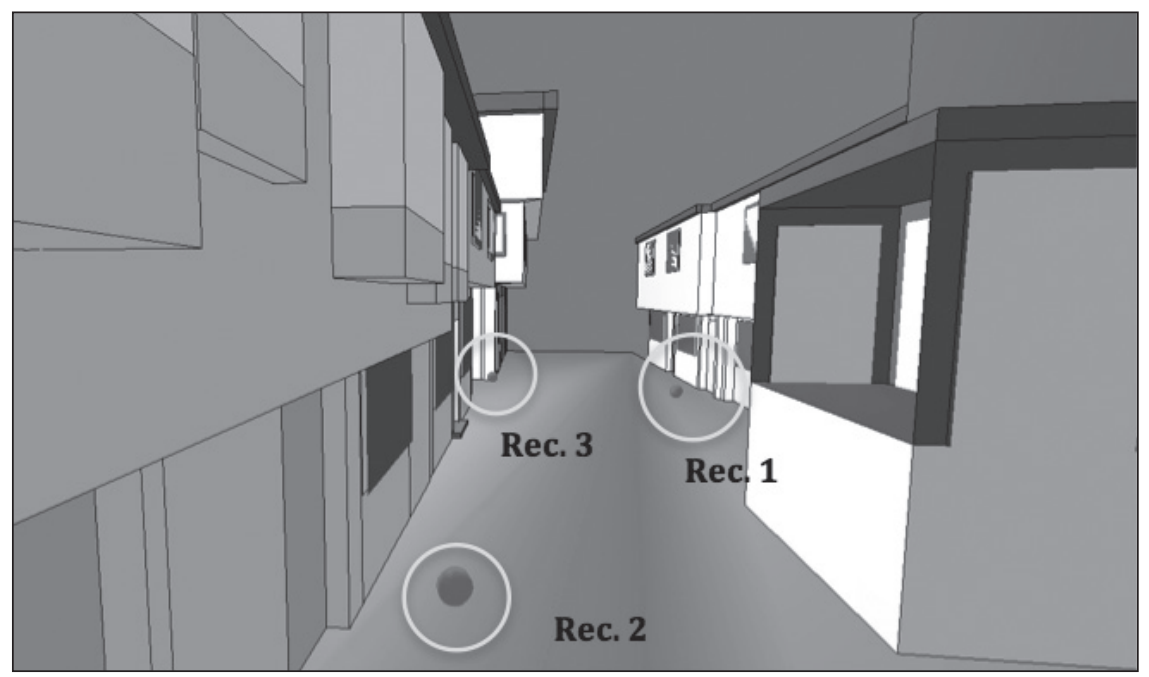

Figure 6. Receiver positions with a side-on orientation

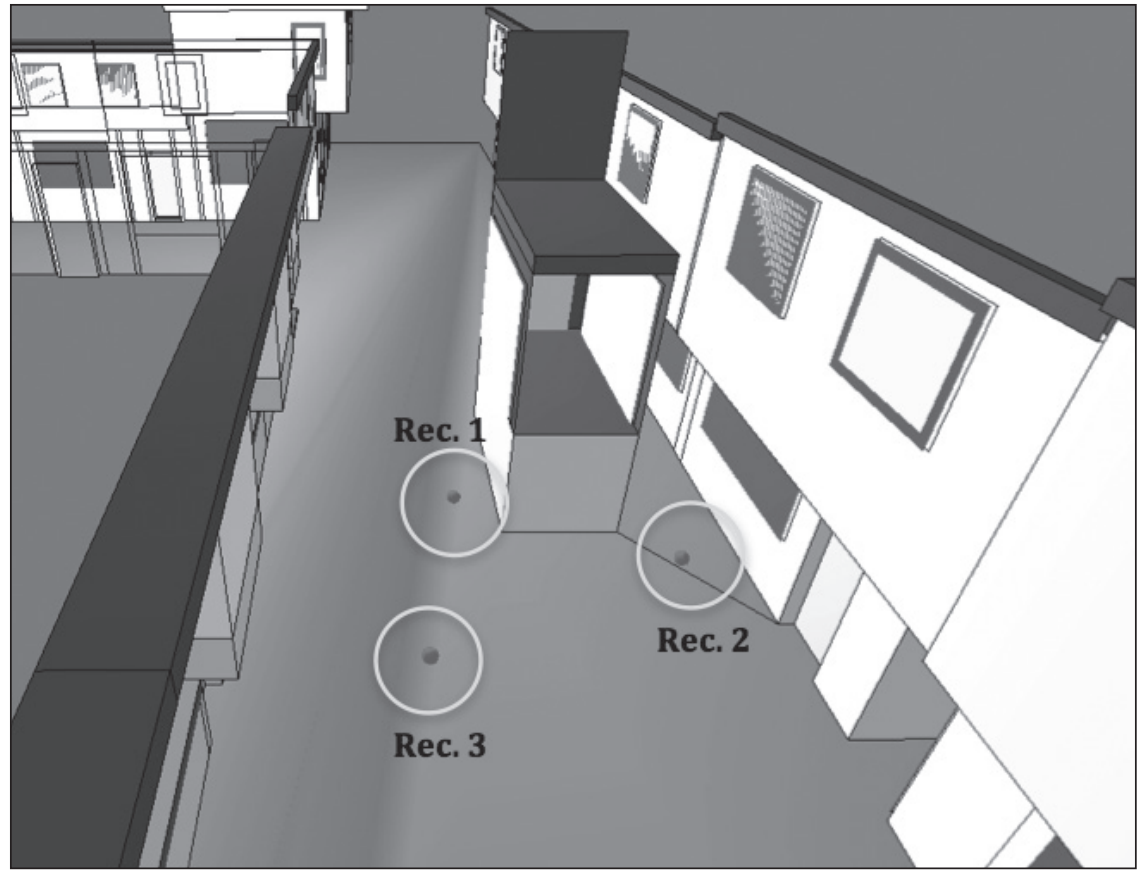

Figure 7. Receiver positions with a front-on orientation 
In a space used for music performances, the optimum reverberation time depends on the type of music performed. Music characterized by short notes and complex rhythmic patterns will benefit from short reverberation times that enable the listener to distinguish every note, while slow and rhythmically simple music would benefit from longer reverberation times. ${ }^{30}$ Table 4 includes values of reverberation time associated with spaces used for dramatic and musical performances as well as medieval religious sites.

Table 4. Reverberation time values linked to spaces used for dramatic and musical per-

formances as well as medieval religious sites in Yorkshire

\begin{tabular}{lc}
\hline \multicolumn{1}{c}{ function of the space/specific site } & reverberation time (seconds) \\
\hline drama & $0.7 \mathrm{~s}-1.2 \mathrm{~s}^{31}$ \\
baroque music & $1.5 \mathrm{~s}^{32}$ \\
classical music & $1.7 \mathrm{~s}^{33}$ \\
Wagnerian opera & $1.7 \mathrm{~s}^{34}$ \\
symphonic music & $1.9 \mathrm{~s}^{35}$ \\
romantic music & $2.2 \mathrm{~s}^{36}$ \\
York Minster & $6.1 \mathrm{~s}^{37}$ \\
St Patrick's Patrington parish church (East Yorkshire, 15th & $3.5 \mathrm{~s}^{38}$ \\
century) & \\
\hline
\end{tabular}

Clarity is an early-to-late arriving energy ratio expressed in decibels. When calculated as C50, it considers the division between early and late energy as 50 milliseconds (ms) and gives an indication of speech intelligibility in a space, whereas when calculated as C80, it considers the division between early and late energy as $80 \mathrm{~ms}$ and measures musical definition. As was noted in connection to reverberation time, optimum values are highly dependent on the use of the space. Higher values of clarity would result in better speech intelligibility and the perception of musical detail. Those listening to rhythmically complex musical items will prefer high levels of clarity since each sound will be more distinct; performances of, for instance, plainchant items, which present slow melodic lines, would benefit from lower values of clarity. Michael Barron ${ }^{39}$ indicates that optimum values of clarity for concert halls 
are within the range of $-2 \mathrm{~dB}$ to $+2 \mathrm{~dB}$. Although higher values would likely not indicate an excess of clarity, we need to assess whether higher values are indicating very low results in other parameters, such as reverberation time. ${ }^{40}$ Clarity values linked to concert halls as well as medieval sites can be found in table 5 .

Table 5. Clarity values linked to spaces used for musical performances and medieval religious sites in Yorkshire

\begin{tabular}{lc}
\hline \multicolumn{1}{c}{ function of the space/specific site } & clarity (dB) \\
\hline concert hall & $-2 \mathrm{~dB}$ to $+2 \mathrm{~dB}(\mathrm{C} 50 / \mathrm{C} 80)^{41}$ \\
York Minster & $-6.09 \mathrm{~dB}(\mathrm{C} 50) /-5.40 \mathrm{~dB}(\mathrm{C} 80)^{42}$ \\
St Patrick's Patrington parish church (East Yorkshire, & $-8 \mathrm{~dB}(\mathrm{C} 80)^{43}$ \\
15th century) & \\
\hline
\end{tabular}

The ASW is associated with the perceptual broadening of the sound source related to the presence of early (first $80 \mathrm{~ms}$ ) lateral reflections ${ }^{44}$ and it is a characteristic favourable to music performances. We can analyse ASW by using the parameter $\mathrm{IACC}_{\mathrm{E}}$ (Interaural Cross-Correlation Coefficient, Early), which measures the dissimilarity of signals arriving at both ears. It is often calculated as $\mathrm{IACC}_{\mathrm{E} 3}$, which is the mean $\mathrm{IACC}_{\mathrm{E}}$ across $500 \mathrm{~Hz}-2 \mathrm{kHz}$. Calculations consider the $500 \mathrm{~Hz}-2 \mathrm{kHz}$ range due to the fact that the wavelength (the distance travelled by a wave within a cycle) is similar or smaller than the dimensions of an average listener's head. ${ }^{45} \mathrm{IACC}_{\mathrm{E} 3}$ negatively correlates with the ASW, meaning that an increase in $\mathrm{IACC}_{\mathrm{E} 3}$ corresponds to a decrease in ASW (and vice versa). Subjective studies have shown that audiences prefer low values of IACC $_{E}$, which indicate a perceptual broadening of the source. ${ }^{46} \mathrm{IACC}_{\mathrm{E} 3}$ values linked to spaces used for musical performances and medieval religious sites can be found in table 6 .

Table 6. IACC $\mathrm{E}_{\mathrm{E}}$ values linked to spaces used for musical performances and medieval religious sites

\begin{tabular}{lcc}
\hline & function of the space/specific site & IACC $_{\mathrm{E} 3}$ \\
\hline concert halls & ranked as "superior" and "excellent" & $0.36-0.46^{47}$ \\
& ranked as "good" to "excellent" & $0.38-0.54^{48}$ \\
ranked as "good" & $0.53-0.59^{49}$ \\
Gothic churches & & $0.15-0.78^{50}$ \\
\hline
\end{tabular}


I determined significant differences in the acoustics of a space through the calculation of the Just Noticeable Difference (JND), which can be defined as the smallest perceptible difference between samples. For this research project, I used a JND value of $5 \%{ }^{51}$ for T30 when values were larger than $0.6 \mathrm{~s}$, and assumed a fixed value of $0.03 \mathrm{~s}$ for reverberation times shorter than $0.6 s^{52} \mathrm{JND}$ values for $\mathrm{C} 50$ and $\mathrm{C} 80$ were $1.1 \mathrm{~dB}$ and $1 \mathrm{~dB}$ respectively. ${ }^{53}$ The JND for $\mathrm{IACC}_{\mathrm{E} 3}$ was $0.075 .^{54}$

\section{Acoustical Analysis}

\section{Impact of Wagon Structures on Sixteenth-Century Stonegate}

This section explores the data collected from the combination of the different wagons with the various virtual models of Stonegate and compares it to the data collected for the virtual models of the street space without the inclusion of a wagon structure.

The addition of a wagon structure to the street space resulted in variations in all the acoustical parameters studied. In terms of reverberation time, we observed a clear tendency towards a decrease in values. The exception to this decrease was the combination of the closed wagon in a side-on orientation and Stonegate 2-4, which resulted in longer reverberation times.

The impact of the addition of a wagon structure on clarity depended heavily on the simulation of Stonegate, making it more difficult to arrive at a generalization. In the case of Stonegate 1, clarity increased when a closed wagon (regardless of the orientation) and an open wagon in a front-on orientation were used, but decreased when the open wagon in a side-on orientation was included in the street space. Results for Stonegate 3 and 4 also showed higher clarity with the inclusion of a wagon. This higher clarity, however, is only the case with the closed wagon in a front-on orientation and with the open wagon with both orientations. When considering Stonegate 2, the closed wagon and the open wagon in a side-on orientation result in a decrease in clarity, whereas the inclusion of the open wagon in a front-on orientation results in an increase. Changes in spatial impression indicated that the inclusion of wagon structures caused an increase in the ASW.

\section{Impact of Closed and Open Wagon Structures on Sixteenth-Century Stonegate} The following section analyses the differences in the acoustics of Stonegate depending on whether a closed or an open wagon is used. Such analysis compares each orientation, side-on and front-on, separately. This way of pairing 
the simulations avoids the tainting of comparisons resulting from wagon orientation.

\section{Comparison Between Side-On Wagons}

I studied the impact of closed and open wagons on sixteenth-century Stonegate by comparing the two structures in a side-on orientation. Reverberation time results (see table 7) indicate that with Stonegate 1 the open wagon had the longest reverberation time, whereas Stonegate 2 and 4 showed opposite results since in these simulations the use of the closed wagon resulted in a longer reverberation time. Stonegate 3 was the least affected of the simulations and the significant differences recorded did not indicate any clear tendencies. The reverberation time calculated in all simulations is below that considered ideal for theatre performances (1s). ${ }^{55}$ The combination of Stonegate 3 with either a closed or an open wagon in a side-on orientation, however, results in values within the range measured for theatres, $0.7-1.2 \mathrm{~s} .{ }^{56}$

The reverberation time in all simulations is below the values found in spaces where plainchant and polyphonic pieces would have been sung on a regular basis. This lower reverberation time would have impacted both listeners and singers. Listeners would have been unaccustomed to hearing the pieces in such an acoustical setting, whereas performers would have had to adapt their singing to a dryer space (that is, with shorter reverberation times), which would not have provided as much auditory feedback and might result in greater difficulty in maintaining a proper intonation.

Clarity results (see table 7) showed that Stonegate 2 was the most affected and had higher clarity when the open wagon was used, although at $1-16 \mathrm{kHz}$ higher values for the closed wagon could also be observed. Stonegate 1, 3 and 4 exhibit higher clarity at $125-500 \mathrm{~Hz}$ when the open wagon is used and at $1-16 \mathrm{kHz}$ when the closed wagon is incorporated. Despite these differences all simulations indicate results that would ensure speech intelligibility. 
Table 7. Range of values recorded for the closed and open wagons with a side-on orientation

\begin{tabular}{|c|c|c|c|c|c|c|}
\hline & & & \multicolumn{4}{|c|}{ results per parameter } \\
\hline \multicolumn{2}{|c|}{ virtual model } & range & $\mathrm{T}_{30}$ & $\mathrm{C}_{50}$ & $\mathrm{C}_{80}$ & $\mathrm{IACC}_{\mathrm{E} 3}$ \\
\hline \multirow[t]{4}{*}{ Stonegate 1} & closed wagon & $\min$ & $0.31 \mathrm{~s}$ & $5.66 \mathrm{~dB}$ & $8.83 \mathrm{~dB}$ & 0.28 \\
\hline & & $\max$ & $0.68 s$ & $14.89 \mathrm{~dB}$ & $21.77 \mathrm{~dB}$ & 0.68 \\
\hline & open wagon & $\min$ & $0.32 \mathrm{~s}$ & $2.88 \mathrm{~dB}$ & $5.94 \mathrm{~dB}$ & 0.38 \\
\hline & & $\max$ & $0.7 \mathrm{~s}$ & $13.09 \mathrm{~dB}$ & $19.66 \mathrm{~dB}$ & 0.67 \\
\hline \multirow[t]{4}{*}{ Stonegate 2} & closed wagon & $\min$. & $0.26 \mathrm{~s}$ & $6.04 \mathrm{~dB}$ & $9.63 \mathrm{~dB}$ & 0.29 \\
\hline & & $\max$ & $0.56 \mathrm{~s}$ & $18.63 \mathrm{~dB}$ & $25.5 \mathrm{~dB}$ & 0.73 \\
\hline & open wagon & $\min$ & $0.27 \mathrm{~s}$ & $6.94 \mathrm{~dB}$ & $13.05 \mathrm{~dB}$ & 0.32 \\
\hline & & $\max$ & $0.52 \mathrm{~s}$ & $16.31 \mathrm{~dB}$ & $23.03 \mathrm{~dB}$ & 0.72 \\
\hline \multirow[t]{4}{*}{ Stonegate 3} & closed wagon & $\min$. & $0.35 \mathrm{~s}$ & $3.51 \mathrm{~dB}$ & $6.64 \mathrm{~dB}$ & 0.3 \\
\hline & & $\max$ & $0.84 \mathrm{~s}$ & $15.22 \mathrm{~dB}$ & $20.77 \mathrm{~dB}$ & 0.63 \\
\hline & open wagon & $\min$. & $0.36 \mathrm{~s}$ & $4.19 \mathrm{~dB}$ & $7.97 \mathrm{~dB}$ & 0.42 \\
\hline & & $\max$ & $0.79 \mathrm{~s}$ & $12.51 \mathrm{~dB}$ & $18.94 \mathrm{~dB}$ & 0.68 \\
\hline \multirow[t]{4}{*}{ Stonegate 4} & closed wagon & $\min$. & $0.29 \mathrm{~s}$ & $3.28 \mathrm{~dB}$ & $6.25 \mathrm{~dB}$ & 0.3 \\
\hline & & $\max$ & $0.68 s$ & $17.13 \mathrm{~dB}$ & $23.77 \mathrm{~dB}$ & 0.69 \\
\hline & open wagon & $\min$ & $0.31 \mathrm{~s}$ & $5.7 \mathrm{~dB}$ & $10.00 \mathrm{~dB}$ & 0.4 \\
\hline & & $\max$ & $0.6 \mathrm{~s}$ & $15.5 \mathrm{~dB}$ & $21.32 \mathrm{~dB}$ & 0.66 \\
\hline
\end{tabular}

Clarity is very high for the performance of plainchant items, although it might benefit the most complex polyphonic pieces whose rhythms would have been perceived more distinctively. The high clarity nevertheless comes at the expense of the reverberation time and thus might cause discomfort to singers.

The examination of $\mathrm{IACC}_{\mathrm{E} 3}$ showed that, although the parameter presented variations in the results, these variations did not indicate a clear 
tendency and depended upon the source and receiver positions. Stonegate 1 and 3 combined with a closed wagon have the lowest values of IACC $_{\mathrm{E} 3}$, which means that they present a greater perceptual broadening of the sound source.

\section{Comparison Between Front-On Wagons}

The comparison between the wagon structures in a front-on orientation proved that the impact of the change in wagon type is larger when front-on wagons are used (see table 8 ). Reverberation time results were affected the most when considering Stonegate 1, 3, and 4, and the use of the open wagon resulted in the longest reverberation time. Stonegate 2, however, exhibited a longer reverberation time for the open wagon only when sources B0 and B1 were used, whereas the use of source B2 resulted in higher values for the closed wagon. Reverberation time values are below 1 second in all the simulations, and Stonegate 3, both with a closed and an open wagon, has values within the range associated with theatres. The combination with the open wagon, furthermore, presents the longest reverberation time. As observed when analysing the side-on wagons, the reverberation time values recorded in all the computer models are lower than those generally associated with music performances.

Clarity values were affected the most with the simulation of Stonegate 2. Although most of the differences showed that the open wagon resulted in higher clarity, observation also revealed that at $2-16 \mathrm{kHz}$ values are higher when the closed wagon is included in the street space. The simulations of Stonegate 1, 3, and 4 show that the inclusion of the open wagon results in higher values at $125-500 \mathrm{~Hz}$, whereas at $1-16 \mathrm{kHz}$ the closed wagon has higher clarity. All clarity values in all the simulations are appropriate for speech, but they are above those recommended for music.

The analysis of $\mathrm{IACC}_{\mathrm{E} 3}$ showed a clear correlation between the use of the open wagon and the increase in ASW. Spatial impression values are suitable for music, in particular when using the open wagon combined with Stonegate 3, which has values found in concert halls. 
Table 8. Range of values recorded for the closed and open wagons with a front-on orientation

\begin{tabular}{|c|c|c|c|c|c|c|}
\hline & & & \multicolumn{4}{|c|}{ results per parameter } \\
\hline \multicolumn{2}{|c|}{ virtual model } & range & $\mathrm{T}_{30}$ & $\mathrm{C}_{50}$ & $\mathrm{C}_{80}$ & $\mathrm{IACC}_{\mathrm{E} 3}$ \\
\hline \multirow[t]{4}{*}{ Stonegate 1} & closed wagon & $\min$. & $0.27 \mathrm{~s}$ & $3.63 \mathrm{~dB}$ & $7.68 \mathrm{~dB}$ & 0.28 \\
\hline & & $\max$ & $0.62 \mathrm{~s}$ & $19.05 \mathrm{~dB}$ & $24.94 \mathrm{~dB}$ & 0.59 \\
\hline & open wagon & $\min$. & $0.3 \mathrm{~s}$ & $5.62 \mathrm{~dB}$ & $9.29 \mathrm{~dB}$ & 0.24 \\
\hline & & $\max$ & $0.65 s$ & $19.11 \mathrm{~dB}$ & $24.28 \mathrm{~dB}$ & 0.56 \\
\hline \multirow[t]{4}{*}{ Stonegate 2} & closed wagon & $\min$. & $0.26 \mathrm{~s}$ & $5.50 \mathrm{~dB}$ & $9.54 \mathrm{~dB}$ & 0.35 \\
\hline & & $\max$ & $0.5 \mathrm{~s}$ & $19.62 \mathrm{~dB}$ & $25.61 \mathrm{~dB}$ & 0.61 \\
\hline & open wagon & $\min$. & $0.25 \mathrm{~s}$ & $8.73 \mathrm{~dB}$ & $12.80 \mathrm{~dB}$ & 0.2 \\
\hline & & $\max$ & $0.52 \mathrm{~s}$ & $20.24 \mathrm{~dB}$ & $26.68 \mathrm{~dB}$ & 0.66 \\
\hline \multirow[t]{4}{*}{ Stonegate 3} & closed wagon & $\min$. & $0.31 \mathrm{~s}$ & $2.60 \mathrm{~dB}$ & $7.02 \mathrm{~dB}$ & 0.35 \\
\hline & & $\max$ & $0.75 \mathrm{~s}$ & $18.13 \mathrm{~dB}$ & $23.39 \mathrm{~dB}$ & 0.61 \\
\hline & open wagon & $\min$. & $0.32 \mathrm{~s}$ & $4.52 \mathrm{~dB}$ & $7.94 \mathrm{~dB}$ & 0.25 \\
\hline & & $\max$ & $0.75 s$ & $16.61 \mathrm{~dB}$ & $22.07 \mathrm{~dB}$ & 0.55 \\
\hline \multirow[t]{4}{*}{ Stonegate 4} & closed wagon & $\min$. & $0.27 \mathrm{~s}$ & $3.83 \mathrm{~dB}$ & $9.56 \mathrm{~dB}$ & 0.27 \\
\hline & & $\max$ & $0.58 \mathrm{~s}$ & $19.16 \mathrm{~dB}$ & $25.23 \mathrm{~dB}$ & 0.63 \\
\hline & open wagon & $\min$. & $0.28 s$ & $6.98 \mathrm{~dB}$ & $10.76 \mathrm{~dB}$ & 0.29 \\
\hline & & $\max$ & $0.64 \mathrm{~s}$ & $19.06 \mathrm{~dB}$ & $24.14 \mathrm{~dB}$ & 0.61 \\
\hline
\end{tabular}

Impact of Side-On and Front-On Wagon Orientations on Sixteenth-Century Stonegate

This section reflects on the acoustical effects of side-on vs. front-on wagons. I conducted the analysis by grouping the closed wagons on the one hand, and the open wagons on the other. This grouping enables the study of the influence of the orientation on each type of wagon. 
Comparison Between Different Orientations of the Closed Wagon

Changes in wagon orientation affected all simulations, as well as all parameters studied (see table 9). The side-on orientation resulted in a longer reverberation time. The longest value was recorded for Stonegate 3 and was within the range considered suitable for theatres, though below one second. These values, however, are outside the ranges considered suitable for music performances.

Table 9. Range of values recorded for the side-on and front-on orientation of the closed wagon structure

\begin{tabular}{|c|c|c|c|c|c|c|}
\hline \multirow{2}{*}{\multicolumn{2}{|c|}{ virtual model }} & \multirow{3}{*}{$\frac{\text { range }}{\text { min. }}$} & \multicolumn{4}{|c|}{ results per parameter } \\
\hline & & & \multirow{2}{*}{$\frac{\mathrm{T}_{30}}{0.31 \mathrm{~s}}$} & \multirow{2}{*}{$\frac{\mathrm{C}_{50}}{5.66 \mathrm{~dB}}$} & \multirow{2}{*}{$\frac{\mathrm{C}_{80}}{8.83 \mathrm{~dB}}$} & \multirow{2}{*}{$\frac{\text { IACC }_{\mathrm{E} 3}}{0.28}$} \\
\hline Stonegate 1 & side-on & & & & & \\
\hline & & $\max$ & $0.72 \mathrm{~s}$ & $14.89 \mathrm{~dB}$ & $21.77 \mathrm{~dB}$ & 0.76 \\
\hline & front-on & $\min$ & $0.27 \mathrm{~s}$ & $3.63 \mathrm{~dB}$ & $7.68 \mathrm{~dB}$ & 0.28 \\
\hline & & $\max$ & $0.62 s$ & $19.05 \mathrm{~dB}$ & $24.94 \mathrm{~dB}$ & 0.59 \\
\hline \multirow[t]{4}{*}{ Stonegate 2} & side-on & $\min$ & $0.26 \mathrm{~s}$ & $6.04 \mathrm{~dB}$ & $9.63 \mathrm{~dB}$ & 0.28 \\
\hline & & $\max$ & $0.56 \mathrm{~s}$ & $18.63 \mathrm{~dB}$ & $25.5 \mathrm{~dB}$ & 0.76 \\
\hline & front-on & $\min$ & $0.26 \mathrm{~s}$ & $5.50 \mathrm{~dB}$ & $9.54 \mathrm{~dB}$ & 0.35 \\
\hline & & $\max$ & $0.5 \mathrm{~s}$ & $19.62 \mathrm{~dB}$ & $25.61 \mathrm{~dB}$ & 0.61 \\
\hline \multirow[t]{4}{*}{ Stonegate 3} & side-on & $\min$ & $0.35 \mathrm{~s}$ & $0.42 \mathrm{~dB}$ & $3.84 \mathrm{~dB}$ & 0.3 \\
\hline & & $\max$ & $0.84 \mathrm{~s}$ & $15.22 \mathrm{~dB}$ & $20.77 \mathrm{~dB}$ & 0.68 \\
\hline & front-on & $\min$ & $0.31 \mathrm{~s}$ & $2.60 \mathrm{~dB}$ & $7.02 \mathrm{~dB}$ & 0.35 \\
\hline & & $\max$ & $0.75 \mathrm{~s}$ & $18.13 \mathrm{~dB}$ & $23.39 \mathrm{~dB}$ & 0.61 \\
\hline \multirow[t]{4}{*}{ Stonegate 4} & side-on & $\min$ & $0.29 s$ & $2.18 \mathrm{~dB}$ & $6.25 \mathrm{~dB}$ & 0.3 \\
\hline & & $\max$ & $0.68 s$ & $17.13 \mathrm{~dB}$ & $23.77 \mathrm{~dB}$ & 0.69 \\
\hline & front-on & $\min$ & $0.27 \mathrm{~s}$ & $3.83 \mathrm{~dB}$ & $9.56 \mathrm{~dB}$ & 0.27 \\
\hline & & $\max$ & $0.58 s$ & $19.16 \mathrm{~dB}$ & $25.23 \mathrm{~dB}$ & 0.63 \\
\hline
\end{tabular}


The analysis of C50 and C80 proved that the use of a front-on wagon resulted in higher levels of clarity in the performance space. Clarity values are suitable for speech intelligibility in all the simulations but outside the ranges considered suitable for music performances.

Finally, the study of $\mathrm{IACC}_{\mathrm{E} 3}$ proved an increase in the ASW that is associated with the use of the front-on orientation. $\mathrm{IACC}_{\mathrm{E} 3}$ presents good results for music and Stonegate 1 with a front-on wagon has values comparable to those recorded for concert halls.

\section{Comparison Between Different Orientations of the Open Wagon}

The change in wagon orientation affected all simulations as well as all parameters studied (see table 10). When analysing the parameters T30 and $\mathrm{IACC}_{\mathrm{E} 3}$ I noted that, although the use of different orientations for the open wagon resulted in significant differences, these differences were not as prominent as those observed for the closed wagon structure.

The examination of T30 results showed that the use of the open wagon in a side-on orientation resulted in longer reverberation times, whereas the use of the front-on orientation resulted in higher values of clarity. The study of $\mathrm{IACC}_{\mathrm{E} 3}$ proved an increase in spaciousness is associated with the use of a front-on orientation.

The longest reverberation time was recorded for the combination of Stonegate 3 with a side-on wagon, including values suitable for theatres, and all clarity results show the suitability of the space in terms of speech intelligibility.

The reverberation time and clarity results are outside the ranges deemed suitable for musical performances. The spatial impression, on the other hand, seems more adequate. The combination of Stonegate 1 with an open front-on wagon, for example, resulted in $\mathrm{IACC}_{\mathrm{E} 3}$ values comparable to those recorded for concert halls. 
Table 10. Range of values recorded for the side-on and front-on orientation of the open wagon structure

\begin{tabular}{|c|c|c|c|c|c|c|}
\hline & & \multirow{3}{*}{$\begin{array}{l}\text { range } \\
\text { min. }\end{array}$} & \multicolumn{4}{|c|}{ results per parameter } \\
\hline \multicolumn{2}{|c|}{ virtual model } & & \multirow{2}{*}{$\frac{\mathrm{T}_{30}}{0.32 \mathrm{~s}}$} & \multirow{2}{*}{$\frac{\mathrm{C}_{50}}{2.88 \mathrm{~dB}}$} & \multirow{2}{*}{$\frac{\mathrm{C}_{80}}{5.94 \mathrm{~dB}}$} & \multirow{2}{*}{$\begin{array}{c}\text { IACC }_{\mathrm{E} 3} \\
0.38\end{array}$} \\
\hline Stonegate 1 & side-on & & & & & \\
\hline & & $\max$ & $0.7 \mathrm{~s}$ & $13.09 \mathrm{~dB}$ & $19.66 \mathrm{~dB}$ & 0.67 \\
\hline & front-on & $\min$. & $0.3 \mathrm{~s}$ & $5.62 \mathrm{~dB}$ & $9.29 \mathrm{~dB}$ & 0.24 \\
\hline & & $\max$ & $0.65 \mathrm{~s}$ & $19.11 \mathrm{~dB}$ & $24.28 \mathrm{~dB}$ & 0.56 \\
\hline \multirow[t]{4}{*}{ Stonegate 2} & side-on & $\min$ & $0.27 \mathrm{~s}$ & $6.94 \mathrm{~dB}$ & $13.05 \mathrm{~dB}$ & 0.32 \\
\hline & & $\max$ & $0.52 \mathrm{~s}$ & $16.31 \mathrm{~dB}$ & $23.03 \mathrm{~dB}$ & 0.72 \\
\hline & front-on & $\min$. & $0.25 \mathrm{~s}$ & $8.73 \mathrm{~dB}$ & $12.80 \mathrm{~dB}$ & 0.2 \\
\hline & & $\max$ & $0.52 \mathrm{~s}$ & $20.24 \mathrm{~dB}$ & $26.68 \mathrm{~dB}$ & 0.66 \\
\hline \multirow[t]{4}{*}{ Stonegate 3} & side-on & $\min$. & $0.36 \mathrm{~s}$ & $4.19 \mathrm{~dB}$ & $7.97 \mathrm{~dB}$ & 0.42 \\
\hline & & $\max$ & $0.79 \mathrm{~s}$ & $12.51 \mathrm{~dB}$ & $18.94 \mathrm{~dB}$ & 0.68 \\
\hline & front-on & $\min$ & $0.32 \mathrm{~s}$ & $4.52 \mathrm{~dB}$ & $7.94 \mathrm{~dB}$ & 0.25 \\
\hline & & $\max$ & $0.75 \mathrm{~s}$ & $16.61 \mathrm{~dB}$ & $22.07 \mathrm{~dB}$ & 0.55 \\
\hline \multirow[t]{4}{*}{ Stonegate 4} & side-on & $\min$. & $0.31 \mathrm{~s}$ & $5.7 \mathrm{~dB}$ & $10.00 \mathrm{~dB}$ & 0.4 \\
\hline & & $\max$ & $0.6 \mathrm{~s}$ & $15.5 \mathrm{~dB}$ & $21.32 \mathrm{~dB}$ & 0.66 \\
\hline & front-on & $\min$ & $0.28 \mathrm{~s}$ & $6.98 \mathrm{~dB}$ & $10.76 \mathrm{~dB}$ & 0.29 \\
\hline & & $\max$ & $0.64 \mathrm{~s}$ & $19.06 \mathrm{~dB}$ & $24.14 \mathrm{~dB}$ & 0.61 \\
\hline
\end{tabular}

\section{Conclusions}

This paper explored different hypotheses on staging configurations by examining what their effects might have been in relation to the acoustics of sixteenth-century Stonegate. This exploration was achieved through the simulation of two different wagon structures in two different orientations. In my 
analysis, however, I focussed not just on these elements but also studied how they interacted with different simulations of sixteenth-century Stonegate. I conducted the acoustical analysis through an examination of the results of reverberation time (T30), clarity (C50 and C80), and spatial impression $\left(\mathrm{IACC}_{\mathrm{E} 3}\right)$.

The results showed that the inclusion of a wagon structure affected all parameters. Reverberation time, in most cases, presented a drop in values, whereas clarity evidenced an increase. The $\mathrm{IACC}_{\mathrm{E} 3}$ parameter showed a tendency towards an improvement of the Apparent Source Width (ASW).

Variations in the acoustical parameters also emerged between the wagon structures closed on three sides and those open on all sides. Changes in the structure when using the side-on orientation affected Stonegate 1 and 4 the most. Stonegate 1 had the longest reverberation time when an open wagon was used, whereas Stonegate 4 had the longest reverberation time when the closed wagon was used. The study of the front-on wagons indicated a more straightforward correlation between the use of an open structure and the increase in reverberation time. Clarity parameters were more sensitive to the change and, in general, results evidenced an increase in clarity when the closed wagon was incorporated. The examination of $\mathrm{IACC}_{\mathrm{E} 3}$ in relation to the side-on wagons demonstrated that the results are highly dependent on the receiver position, whereas the study of front-on wagons showed a larger ASW with the use of the open wagon.

Wagon orientation had an impact on all acoustical parameters, but such impact was particularly evident with the closed wagon, indicating that, acoustically, wagon orientation was an issue requiring greater consideration when closed wagons were used. The side-on orientation resulted in a higher reverberation time than the front-on wagon, whereas the front-on wagon resulted in higher clarity and a larger ASW. Although clarity and ASW are smaller for the side-on orientation, they are nevertheless still within the range considered appropriate for speech in the case of clarity and music in the case of the ASW. The increase in clarity in the front-on wagon, furthermore, is detrimental to the performance of plainchant items and it comes at the expense of the reverberation time. Therefore, the side-on wagon provides a better balance between the different acoustical requirements of speech and music.

When taking into account all the different simulations of Stonegate presented in this paper, as well as the different wagon types and orientations, the reader can observe that Stonegate 3 combined with a closed, side-on wagon 
provides the most favourable acoustics for the plays as it has the longest reverberation time, making the acoustic conditions more satisfactory for music, but at the same time those values are still within the range found in theatres and considered suitable for speech. Together with the rest of the simulations, furthermore, this combination has high clarity values that ensure intelligibility. Finally, its $\mathrm{IACC}_{\mathrm{E} 3}$ values are within the range found in Gothic churches, where similar musical repertory would have been performed.

The results presented in this article do not aim to provide absolute answers to questions on the relationship between staging and acoustics; on the contrary, the article focuses on the relative values that result from comparing different configurations and analysing the relevance of these in the context of the performance. This study provides an initial insight into the relationship between acoustics, staging, and performance, and further work needs to be conducted in order to strengthen the findings presented. Further experimentation in connection to different possible surface materials for the wagons, for instance, needs to be explored. The exploration of different wagon structures, moreoever, might shed light on different staging possibilities and their impact on the acoustics of the performance space.

\section{Notes}

The work discussed in this paper was part of a PhD project funded by the department of theatre, film, and television at the University of York, the International Office at the University of York, and the Audio Engineering Society. Thanks to Sandra Pauletto, who supervised the project in question. Special thanks to Richard Morris, Damian Murphy, and Chris Robins.

1 For more information see Alexandra Johnston and Margaret Dorrell, 'The Doomsday Pageant of the York Mercers, 1433', Leeds Studies in English, ns5 (1971), 29-34; Alexandra Johnston and Margaret Dorrell, 'The York Mercers and Their Pageant of Doomsday, 1433-1526', Leeds Studies in English, ns6 (1973), 10-35; Alexandra Johnston and Margaret Dorrell (eds.), REED: York (Toronto, 1979); Peter Meredith, 'Development of the York Mercers' Pageant Waggon', Medieval English Theatre 1 (1979), 5-18.

2 For more information see John McKinnell, 'The Medieval Pageant Wagons at York: Their Orientation and Height', Early Theatre 3 (2000), 79-104, doi: 10.12745/ et.3.1.591; Eileen White, 'People and Places: The Social and Topographical Context of Drama in York 1554-1609', PhD diss. (University of Leeds, 1984); Eileen White, 
'Places to Hear the Play in York', Early Theatre 3 (2000), 49-78, doi: 10.12745/ et.3.1.590.

3 Alan Nelson, 'Easter Week Pageants in Valladolid and Medina del Campo', Medieval English Theatre 1 (1979), 62-70; Meg Twycross, 'The Flemish Ommegang and Its Pageant Cars', Medieval English Theatre 2 (1980), 15-41 and 80-92.

4 Margaret Rogerson, 'Raging in the Streets of Medieval York', Early Theatre 3 (2000), 105-25, doi:10.12745/et.3.1.592; Margaret Rogerson, The York Mystery Plays: Performance in the City (York, 2011); Martin Walsh, 'High Places and Travelling Scenes: Some Observations on the Staging of the York Cycle', Early Theatre 3 (2000), 137-54, doi:10.12745/et.3.1.594.

5 Clifford Davidson, Corpus Christi Plays at York: A Context for Religious Drama (New York, 2013); Pamela King, 'Seeing and Hearing: Looking and Listening', Early Theatre 3 (2000), 155-66, doi: 10.12745/et.3.1.595; Pamela King, 'Poetics and Beyond: Noisy Bodies and Aural Variations in Medieval English Outdoor Performance', 14th Triennial Colloquium of the Société Internationale pour l'étude du Théâtre Médiéval, Poznan, Poland, 22-27 July 2013, available at http://www.staff.amu.edu. pl/\%7Epber/Pamela\%20King.pdf ; Eileen White, 'Places for Hearing the Corpus Christi Play in York', Medieval English Theatre 9 (1987), 23-63; White, 'Places to Hear the Play in York', 49-78.

6 Mariana Lopez, Sandra Pauletto, and Gavin Kearney, 'The Application of Impulse Response Measurement Techniques to the Study of the Acoustics of Stonegate, a Performance Space Used in Medieval English Drama', Acta Acustica United with Acustica 99 (2013), 98-109, doi: 10.3813/AAA.918593; Mariana Lopez and Sandra Pauletto, 'The York Mystery Plays: Acoustics and Staging in Stonegate', 14th Triennial Colloquium of the Société Internationale pour l'étude du Théâtre Médiéval, Poznan, Poland, 22-27 July 2013, available at http://www.staff.amu.edu.pl/ pber/ Lopez\%20and\%20Pauletto.pdf; Mariana Lopez, 'Objective Evaluation of a Simulation of the Acoustics of a Medieval Urban Space Used for Dramatic Performances', Applied Acoustics 88 (2015), 38-43, doi: 10.1016/j.apacoust.2014.08.003; Mariana Lopez, 'Using Multiple Computer Models to Study the Acoustics of a SixteenthCentury Performance Space', Applied Acoustics 94 (2015), 14-19, doi:10.1016/j. apacoust.2015.02.002.

7 Mariana Lopez, 'Acoustics, Performers and Audiences in Medieval English Drama', Auditorium Acoustics 2015, Paris, France, 29-31 October 2015.

8 Mariana Lopez, 'Using Multiple Computer Models', 14-19.

9 For more information on arguments in connection to the side-on/front-on orientation of wagons, see John McKinnell, 'Producing the York Mary Plays', Medieval English Theatre 12 (1990), 101-23; McKinnell, 'The Medieval Pageant Wagons at 
York', 79-104; Nelson, 'Easter Week Pageants', 62-70; Meg Twycross, "Places to Hear the Play': Pageant Stations at York, 1398-1572', REED Newsletter 2 (1978), 10-33; Twycross, 'The Flemish Ommegang and Its Pageant Cars', 15-41 and 8092; Meg Twycross, 'The Left-Hand-Side Theory: A Retraction', Medieval English Theatre 14 (1992), 77-94; White, 'People and Places'; White, 'Places for Hearing the Corpus Christi Play in York', 23-63; White, 'Places to Hear the Play in York', 49-78.

10 Johnston and Dorrell, 'The York Mercers', 10-35; Johnston and Dorrell (eds.), REED: York.

11 McKinnell, 'The Medieval Pageant Wagons at York', 79-104.

12 Ibid.

13 Twycross, 'The Flemish Ommegang and Its Pageant Cars', 15-41 and 80-92.

14 McKinnell, 'The Medieval Pageant Wagons at York', 79-104.

15 Ibid.

16 Ibid.

17 Julian Munby, 'From Carriage to Coach: What Happened?', Robert Bork and Andrea Kann (eds.), The Art, Science, and Technology of Medieval Travel (Aldershot, 2008), 41-53.

18 Dalenbäck, CATT-Acoustic.

19 For more information on wagon structures used for the York Mystery Plays see: Johnston and Dorrell, 'The Doomsday Pageant of the York Mercers, 1433', 2934; Johnston and Dorrell, 'The York Mercers', 10-35; Johnston and Dorrell (eds.), REED: York; McKinnell, 'The Medieval Pageant Wagons at York', 79-104; Meredith, 'Development of the York Mercers' Pageant Waggon', 5-18; Nelson, 'Easter Week Pageants', 62-70; Twycross, 'The Flemish Ommegang and Its Pageant Cars', 15-41 and 80-92.

20 Dalenbäck, CATT-Acoustic.

21 See Lopez, Pauletto, and Kearney, 'The Application of Impulse Response Measurement Techniques', 98-109; Lopez, 'Acoustics of a Medieval Urban Space, 38-43.

22 Anders Gade, 'Acoustical Survey of Eleven European Concert Halls - a Basis for Discussion of Halls in Denmark', Technical Report 44 (The Acoustic Laboratory, Technical University of Denmark, 1989).

23 King, 'Seeing and Hearing', 155-66.

24 Johnston and Dorrell (eds.), REED: York; Margaret Rogerson, 'Devotional Acting: Sydney 2008 and Medieval York', Margaret Rogerson (ed.), The York Mystery Plays: Performance in the City (York, 2011), 205-25.

25 Richard Rastall, The Heaven Singing: Music in Early English Religious Drama: I (Cambridge, 1996). 
26 Rastall, The Heaven Singing; Richard Rastall, Minstrels Playing: Music in Early English Religious Drama: II (Cambridge, 2001).

27 Rastall, The Heaven Singing.

28 Michael Barron, Auditorium Acoustics and Architectural Design (London, 1993).

29 Ibid.

30 Leo Beranek, Music, Acoustics \& Architecture (New York and London, 1962).

31 Barron, Auditorium Acoustics and Architectural Design.

32 Beranek, Music, Acoustics \& Architecture.

33 Ibid.

34 Ibid.

35 Ibid.

36 Ibid.

37 Damian Murphy, 'Archaeological Acoustic Space Measurement for Convolution Reverberation and Auralization Applications', Proceedings of the 9th International Conference on Digital Audio Effects (DAFx-06), Montreal, 18-20 September 2006, available at http://www.dafx.ca/proceedings/papers/p_221.pdf.

38 Anthony Masinton, 'Sacred Space: Priorities, Perception and the Presence of God in Late Medieval Yorkshire Parish Churches', PhD diss. (University of York, 2006).

39 Barron, Auditorium Acoustics and Architectural Design.

40 Michael Barron, 'Using the Standard on Objective Measures for Concert Auditoria, ISO 3382, to Give Reliable Results', Acoustical Science and Technology 26.2 (2005), 162-9, doi: 10.1250/ast.26.162.

41 Barron, Auditorium Acoustics and Architectural Design.

42 Damian Murphy and Simon Shelley, The Open Air Library, http://www.openairlib. net/auralizationdb/content/york-minster.

43 Masinton, 'Sacred Space'.

44 John Bradley and Gilbert Soulodre, 'The Influence of Late Arriving Energy on Spatial Impression', Journal of the Acoustical Society of America 97.4 (1995), 2263-71, doi: 10.1121/1.411951.

45 Toshiyuki Okano, Leo Beranek, and Takayuki Hidaka, 'Relations Among Interaural Cross-Correlation Coefficient (IACC $\mathrm{E}$ ), Lateral Fraction $\left(\mathrm{LF}_{\mathrm{E}}\right)$, and Apparent Source Width (ASW) in Concert Halls', Journal of the Acoustical Society of America 104.1 (1998), 255-65, doi: 10.1121/1.423955.

46 M.R. Schroeder, D. Gottlob, and K.F. Siebrasse, 'Comparative Study of European Concert Halls: Correlation of Subjective Preference with Geometric and Acoustic Parameters', Journal of the Acoustical Society of America 56.4 (1974), 1195-1201, doi: 10.1121/1.1903408; Yoichi Ando, Concert Hall Acoustics, (Berlin, 1985). 


\section{Mariana Lopez}

47 Okano, Beranek, and Hidaka, 'Relations Among Interaural Cross-Correlation Coefficient (IACCE), 255-65.

48 Ibid.

49 Ibid.

50 Ettore Cirillo and Francesco Martellotta, Worship, Acoustics and Architecture, (Essex, 2006).

51 ISO 3382-1, 'Acoustics - Measurement of Room Acoustic Parameters. Part 1: Performance Spaces' (Geneva, 2009).

52 T.I. Niaounakis and William J. Davies, 'Perception of Reverberation Time in Small Listening Rooms', Journal of the Audio Engineering Society 50 (2002), 343-50.

53 ISO 3382-1, 'Acoustics — Measurement of Room Acoustic Parameters'; John Bradley, R. Reich, S.G. Norcross, 'A Just Noticeable Difference in C50 for Speech', Applied Acoustics 58 (1999), 99-108, doi: 10.1016/S0003-682X(98)00075-9.

54 ISO 3382-1, 'Acoustics — Measurement of Room Acoustic Parameters'.

55 Barron, Auditorium Acoustics and Architectural Design.

56 Ibid. 